\title{
VISUALIDADE E HUMOR: VISÕES E \\ VERSÕES DE CIÊNCIA EM DESENHOS \\ HUMORÍSTICOS
}

\section{IRENE TOURINHO}

\begin{tabular}{|c|c|}
\hline Resumo & $\begin{array}{l}\text { Nove charges escolhidas na } \\
\text { seção Arte Final da Revista Pesquisa } \\
\text { da Fundação de Amparo à Pesquisa } \\
\text { do Estado de São Paulo - FAPESP } \\
\text { são foco de uma análise que discute } \\
\text { objetivos, métodos, resultados e } \\
\text { implicações da prática científica para } \\
\text { as ciências humanas a partir de } \\
\text { significados e conteúdos simbólicos } \\
\text { expressos nos desenhos. A análise } \\
\text { considera o contexto em que as } \\
\text { charges são apresentadas - uma } \\
\text { revista científica - a representação } \\
\text { da mulher e a opinião de leitores, } \\
\text { apontando idéias, expectativas e } \\
\text { valores que mantêm e questionam } \\
\text { noções convencionais sobre a prática } \\
\text { científica. } \\
\text { Palavras-chave: ciência, humor, } \\
\text { visualidade, prática científica, gênero. }\end{array}$ \\
\hline
\end{tabular}

\section{Abstract}

Selected cartoons from Pesquisa - a monthly Journal of the São Paulo State Foundation for Research Development are a matter of analysis that discusses objectives, methods, results and implications of the scientific practices for the human sciences based on symbolic meanings and contents expressed in the drawings. The analysis considers the context in which such drawings are presented - a scientific journal - the representation of woman and the readers' opinions about the drawings. It suggests ideas, expectations and values that both maintain and question some conventional notions about scientific practices.

Key-words: science, humor, visuality, research practice, gender. 
' PESQUISA é mensal; tiragem: 48.000 exemplares.
Este trabalho discute desenhos humoristicos selecionados da revista científica Pesquisa, da Fundação de Amparo à Pesquisa do Estado de São Paulo - FAPESP, que comemorou 40 anos em julho de $2002^{1}$. A publicação de Pesquisa teve início em outubro de 1999, dando continuidade à publicação Notícias FAPESP. A revista mantém seções referentes a 'Política Científica e Tecnológica', 'Ciência', 'Tecnologia', e 'Humanidades', além de uma seção dedicada às 'Cartas' de leitores e outra a críticas, resenhas de livros, notícias de eventos e lançamentos. Apresenta resultados de projetos de pesquisa e, freqüentemente, publica encartes e suplementos especiais sobre temas que abrangem desde iniciativas de revitalização de bibliotecas, museus e arquivos, até uma retrospectiva sobre 500 anos de ciência e tecnologia no Brasil e avaliações sobre politicas públicas e ensino público. Os desenhos humorísticos aparecem na última folha da revista, numa seção chamada Arte Final. Para este trabalho foram selecionados desenhos do período correspondente a maio de 2000 e junho de 2002, referente aos números 54 a 76 .

Dei preferência às charges com pouco ou nenhum texto, eliminei os cartoons e escolhi desenhos de artistas diferentes. Observei a representação da mulher e li as cartas dos leitores buscando reações, comentários e críticas sobre os desenhos. Aqueles que provocaram os leitores são comentados neste trabalho. Procurei ver como a ciência é representada nestas imagens, que aspectos são reforçados e que leituras as charges oferecem ao estabelecerem um território visual-imagético relacionando ciência e humor.

Perguntas sobre "como o humor é transmitido e por quem, para quem, onde e quando" (Bremmer e Roodenburg, 2000:13) despertaram o interesse para essa discussão. Considerando que "o humor é divertido e sério ao mesmo tempo" (Driessen, 2000:251), a observação- deste duplo caráter permite perceber como os desenhos ora valorizam o caráter humano do fazer científico - suas sensações, desejos e incertezas - e ora reafirmam uma noção de ciência que tenta aprisionar este fazer à racionalidade, objetividade $\mathrm{e}$ neutralidade. Os desenhos mostram esta tensão entre formas conflitantes de conceber a ciência e o cientista, seus métodos e resultados. Criados para uma revista científica, eles têm um caráter público e ao mesmo tempo de conversa entre parceiros já que são vistos predominantemente pela comunidade científica. Estes aspectos ampliam os 
significados dos desenhos e permitem outras possibilidades de leituras além das que apresento. Segundo Driessen, "o humor quase sempre reflete as percepções culturais mais profundas e nos oferece um instrumento poderoso para a compreensão dos modos de pensar e sentir moldados pela cultura" (2000:251).

Quais seriam estes modos de pensar e sentir da cultura cientifica sobre os quais deflagra-se o humor na revista? Que territórios visuais são explorados em relação à ciência? Que temas e valores são reiterados e recrudescem através do riso? Estas, dentre outras questões, guiaram este trabalho. Partimos da compreensão de que a ciência, tanto como a arte, é uma prática que se imbrica 'na' e 'com' a sociedade e sua história. Arte e a ciência carregam ambigüidades e aspiram suplantar uma realidade cotidiana introduzindo nela o impensado e o imprevisível. Apesar dessas características comuns, a ciência, acredita-se, é coisa séria; coisa sempre séria. Já o humor, tanto desestabiliza quanto pode servir de sustentação para a aura de ponderação e circunspeção que envolve a ciência e os cientistas. Ele mostra como a ciência está cercada de convenções e hábitos assim como abriga o acaso e a incerteza.

Através dos desenhos podemos perceber a ausência de um pensamento 'absoluto' ou 'neutro' na ciência e uma constante relação de interesses, projetos e formas de organizar nossas percepções 'científicas' do mundo. Para esta discussão, escolhemos desenhos que possibilitassem examinar aspectos relacionados à noção de cientista e de ciência, tratando especificamente dos seguintes temas: objetivos, métodos, resultados e implicações do fazer científico nas ciências humanas. Através das charges também discutimos a representação da mulher na comunidade científica.

\section{Objetivos da ciência: construindo e questionando identidades}

O primeiro desenho (figura 1) mostra uma máquina imensa, quase-monstro, dominadora, que ininterruptamente produz papeizinhos com respostas para dois cientistas estarrecidos, sufocados pela montanha de papéis que se avoluma e intrigados com uma questão: "Temos todas as respostas, mas qual era mesmo a pergunta?" A sensação é de 
uma avalanche avassaladora de respostas. $O$ espaço que a máquina ocupa sugere sua potência e os cientistas, minimas criaturas de branco, olham a 'máquina-deus', sobre fundo azul-céu e a vêm produzindo uma quantidade desnorteante de respostas. O encontro dos cientistas se dá através da pergunta que é, ela própria, uma busca pela questão inicial que os colocou diante da máquina. A pergunta instaura o

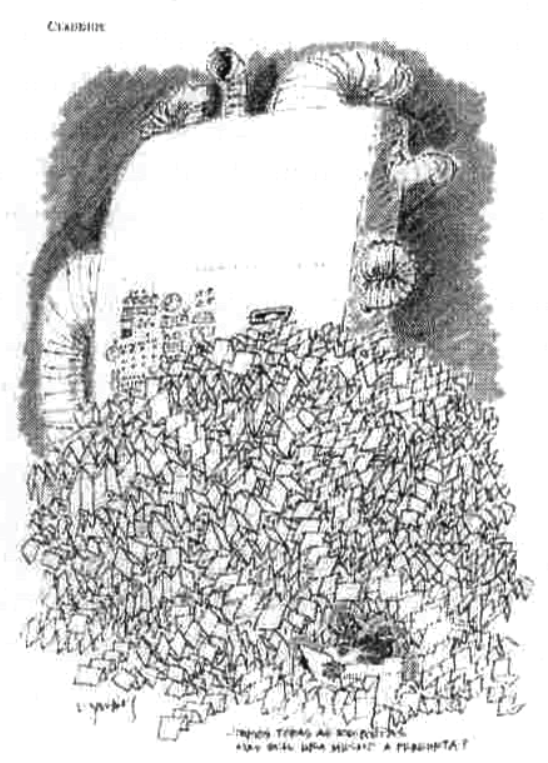

Figura 1

impasse, característico do humor. O desconhecido e o inesperado, da pergunta e da máquina, ocupam lugar de fato.

Saber o que busca, ater-se a suas questōes e ter clareza sobre seus objetivos são condiçб̃es associadas aos cientistas. Neste desenho, sobram respostas, mas falta a pergunta. Indaga-se pela pergunta. É fato que a ciência se desenvolve por meio das perguntas que formula. Mas neste caso a afirmação dos cientistas de que têm "todas as respostas" se contrapōe à busca pela pergunta. Ter todas as respostas 
reforça a autoridade do cientista mas não saber a pergunta fragiliza esta condição. Vêm-se nesta imagem muitas caras do humor: ele subverte e enquadra, surpreende e reafirma. Homem, máquina e ciência formam um imaginário que repleto de posições contraditórias e complementares.

Não associamos à prática científica a imagem de cientistas perdidos em busca de uma pergunta. É sobre a afirmação - 'ter todas as respostas' - que construímos a idéia do cientista. Ela nega 'incertezas' ao processo científico e apela para o sentido de controle e domínio que o cientista deve ter sobre sua especulação. Perdidos, porém achados: esta é a condição dúbia do cientista, instalada pelo humor. Uma máquina, por sua vez, pode ser comumente vista como passivel de oferecer respostas. Mas um enxame invasivo de respostas agrava este sentido: é a máquina incontrolável contra o homem inseguro, vulnerável. É a máquina desnorteando o homem e fazendo-o perder o sentido, a 'origem', a indagação que motivou a busca. Ela engole, corrói e corrompe o pensamento e a memória do homem. O humor ri do homem perdido e surpreso diante da máquina.

Outro desenho (figura 2) amplia a discussão sobre os objetivos da ciência e reforça o caráter multivalente da prática científica nas ciências humanas. Na charge anterior, os objetivos se atrelam à pergunta inicial; nessa, eles chegam aos fins, ao questionamento dos objetivos da ciência. $\mathrm{O}$ desenho mostra um cientista em plena satisfação, quase gozo, diante de uma semi-pronta mulher-robô, objeto de sua busca/ invenção. Ela materializa uma aspiração, realiza o prazer da criação e serve como depositária de desejos (fantasias?) do cientista. O cientista é um homem branco e veste-se de branco. Mostra-se absorto em sua obra, seu trabalho.

A expressão do cientista é de dedicação exclusiva à seu invento e a sua especialidade é revelada não apenas no título do livro que consulta (Robótica III) mas, também, na imagem de um robô, aparentemente do sexo masculino, exposta no quadro que 'ornamenta' a sala/laboratório do cientista. O cientista lê, estuda e tem ares de quem tem experiência no assunto. Ao lado do computador, ferramentas tradicionais de construção sugerem a permanência do desejo humano pela busca do conhecimento e, neste caso, pela satisfação de necessidades, especialmente aquelas ligadas ao corpo.

De calcinha e sutiã, as duas mulheres que aparecem na imagem têm seios avantajados e usam máscaras e chicotes 
2 Personagem da TV brasileira que se apresentava vestida desta maneira e com chicote. (quem sabe ao gosto de uma 'tiazinha'z). A mulher 'real' é gorda, velha, peitos caidos, cabelos curtos e enrolados, mostrando pêlos espalhados pelas pernas. Em primeiro plano e ocupando o maior espaço da imagem, a mulher-invenção é esbelta, jovem, corpo cinturado, cabelos longos e lisos. Seus lábios são vermelhos e bem delineados. A primeira, e a 'outra'. reforçam os estereótipos.

Figura 2

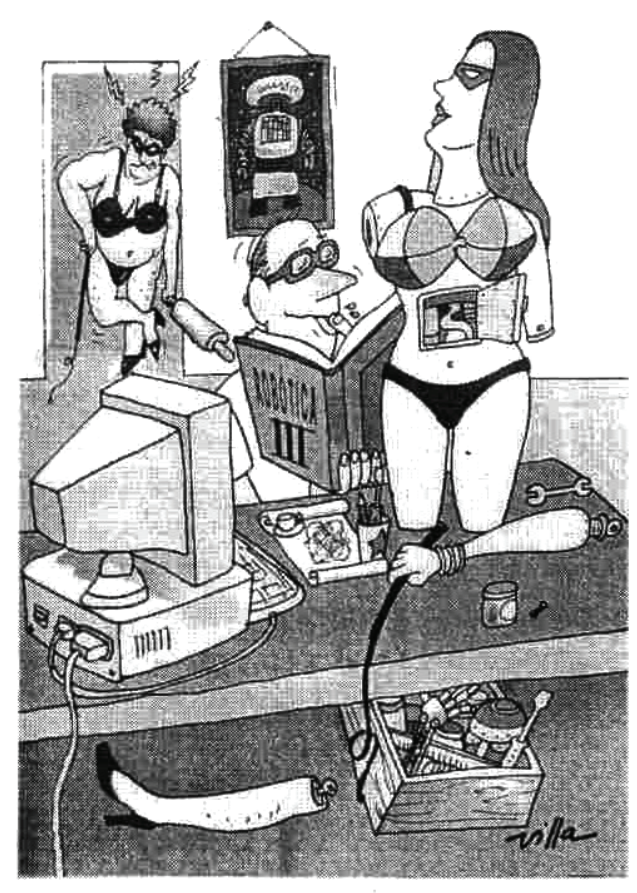

A mulher real expressa raiva, fúria, indignação: a mulher-criação, altivez. firmeza e segurança sobre seu lugar físico e 'espiritual' - no triângulo, nada amoroso. O prazer e 'apetite' do cientista pela sua invenção são demonstrados pelo dedo e a "água-na-boca" que concretizam satisfação e entusiasmo pela nova 'conquista'. Ele desconhece a presença da mulher real, escorada na porta ao fundo, pronta para atacar (quem?) com um rolo de macarrão numa mão e um chicote na outra. A mão da mulher-robó, ainda fora do corpo. 
também segura firme um chicote. Ainda inacabada, a mulher invenção já mostra sua determinação dominadora e agressiva.

Pensar o local de trabalho de um cientista como um refúgio para satisfações de desejos e fantasias do corpo é idéia que contradiz a noção comum da ciência como coisa da mente, séria, neutra. O desenho questiona: de onde vem a sedução: do prazer de criar? Do experimento com a robótica? Da fantasia com as possibilidades de invenção que a ciência promete? Da 'nova' mulher? Corpo e mente se misturam, mas o corpo submete-se à mente. Como o desenvolvimento da robótica está em jogo, o objetivo 'científico' fica resguardado, protegido pela aspiração do desenvolvimento da robótica, especialidade do cientista. O que se torna explícito é a vulnerabilidade da ciência aos desejos mais concretos e imediatos - os da carne - aos mais comuns e caprichosos - da imaginação sexual e aos menos palpáveis e objetivos - os da fantasia. Razão e desejo se misturam na definição dos objetivos científicos.

Falar de corpo é, numa certa medida, falar de gênero. A atitude discriminatória desta imagem em relação aos sexos causa grave incômodo. O chicote, para destacar um elemento, desloca as mulheres, para o início da modernidade e intensifica suas relações com bruxas e feiticeiras. Uma professora do Centro de Ciências Exatas e de Tecnologia da Universidade Federal de São Carlos (SP), leitora da revista, protesta escrevendo: "Lamentei que uma revista como a 'Pesquisa FAPESP' se preste a divulgar matéria de conteúdo sexista (...). Ficam aqui registradas a minha decepção e indignação". A revista não responde à leitora e esta atitude sexista não é incomum nas charges e em outras ilustrações que a Revista apresenta.

Dois números após a publicação desta charge da mulher-robô, a revista publica uma matéria intitulada "Mulheres na Ciência", escrita pela cientista Mayana Zatz após ter recebido o prêmio 'Unesco/L'Oréal for Women in Sciences'. A pesquisadora conta que depois do anúncio do prêmio "as perguntas dos jornalistas nacionais e internacionais eram: Como é ser mulher na ciência?, Quais as 3 Seção 'Opinião', PESQUISA, n.62, março/ 2001. dificuldades que uma mulher cientista enfrenta no Brasil?, Que conselhos você daria às jovens que querem ingressar na carreira científica?” As informações que Zatz apresenta são significativas. Segundo ela, "dados da Unesco", apontam que "apenas $5 \%$ a $10 \%$ das mulheres no mundo galgam funções de 
responsabilidade no campo das ciências" complementando que "ainda hoje, mesmo na Europa e nos Estados Unidos, as mulheres são minoritárias em ciências".

A pesquisadora apresenta também dados do CNPq nos quais "as mulheres constituem $43,7 \%$ das pesquisadoras, apesar de a proporção relativa diminuir com o aumento da faixa etária: $45,9 \%$ a $41,5 \%$ no grupo de 35 a 54 anos e ao redor de $30 \%$ entre 55 e 64 anos. Segundo esta projeção, o número de mulheres vai superar o de homens até o final da década". Mas, de acordo com Zatz, "a questão é: será que isso também vai ocorrer nos postos de liderança?" Ela responde afirmando que "a desproporção sexual é gritante" e comenta que "quando se analisa a porcentagem de mulheres que lideram pesquisas (...) apenas $21 \%$ das mulheres são coordenadoras de projetos temáticos da FAPESP”. Afirma, ainda, que apenas "10\% dos professores titulares da Universidade de São Paulo ou dos membros da Academia Brasileira de Ciências são mulheres".

No mesmo número da Revista onde esta matéria é publicada, ilustrações apresentam grupos de cientistas, todos homens, maduros e de cor branca. Tais ilustrações provocaram a reação de um Professor da Faculdade de Engenharia Química da Universidade de Campinas, SP, que parabeniza a FAPESP pela revista e comenta sobre "um detalhe que ficou mais evidente nesta última edição". Segundo o professor, "mais uma vez vejo um cartoon representando cientistas contento apenas figuras masculinas". Ele sugere "que mulheres (e também negros, orientais, indigenas etc.) apareçam na composição destas ilustrações de cientistas".

É um homem quem questiona esta ausência de representação de mulheres na revista: elas não aparecem na condição de cientista ou, quando são vistas desta maneira, são alvo de uma contradição que reforça a discriminação. Duas charges foram selecionadas para ilustrar este ponto. $\mathrm{Na}$ primeira, (figura 3) homem e mulher dialogam num ambiente mais parecido com um escritório que com um laboratório ou espaço de pesquisa. Quem segura o papel é o homem. Esse detalhe ganha importância quando observamos que papéis, livros e ferramentas são elementos que freqüentemente aparecem nas charges como mediadores da relação entre cientistas e o mundo, atribuindo-lhes autoridade que geralmente associamos às ferramentas - instrumentos da 
ciência - e. com elas, à palavra escrita. Estes elementos sugerem status e criam cenário de mundo cientifico.

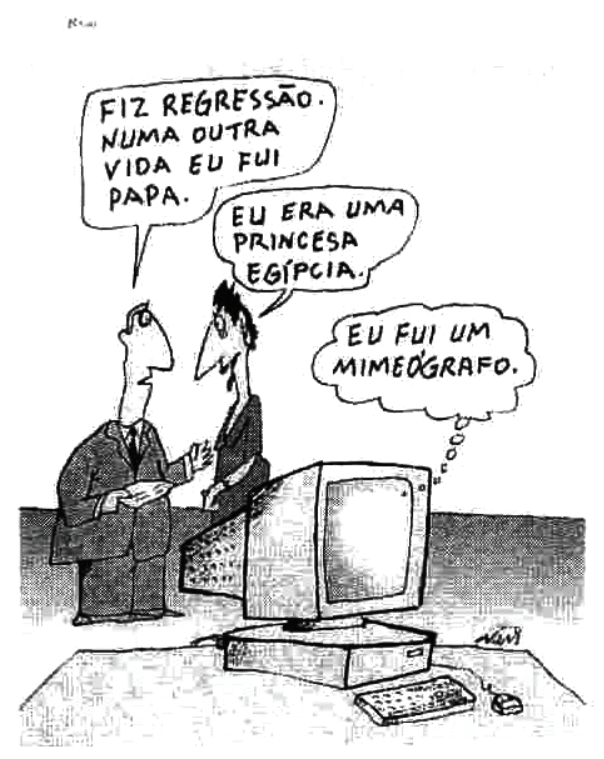

Figura 3

No diálogo da charge, ele foi papa, e ela. princesa egipcia. A figura do papa è uma autoridade ainda presente, forte e convincente. Princesas egipcias (poderia ter sido rainha, por que nāo?) são partes de um tempo remoto, sem rastro na atualidade. A regressão coloca homem, mulher e máquina numa mesma condição, mas apenas a experiência do homem - ser papa - persiste entre nós (o computador, exmimeógrafo, ainda poderia ser lembrança presente em alguma escola, pública talvez...).

$\mathrm{Na}$ charge seguinte (figura 4), a mulher é representada com rolinhos nos cabelos e lenço na cabeça, imagem facilmente associada ao estereótipo de uma doméstica ou dona-de-casa. É uma mulher que se prepara, enquanto faz feira, para estar 'pronta' - num determinado padrão de beleza - mais tarde. É ela, e não, por exemplo, o feirante ou o 
agricultor, que se surpreende e espanta com o monstro dos transgênicos. Fazer a feira é sua função, mesmo que

desinformada. Ao nome 'transgênico' é acrescentado o 's', correção de última hora... Mais uma vez salienta-se o poder da escrita e de suas funções na prática científica. Cuidar de um nome é particularizar uma identidade, criar uma marca, gerar um apelo. O corpo da mulher se retrai, ela faz cara de susto e, desconcertada, encara o 'bicho' ameaçador, agora definitivo e vendido na feira, para todos.

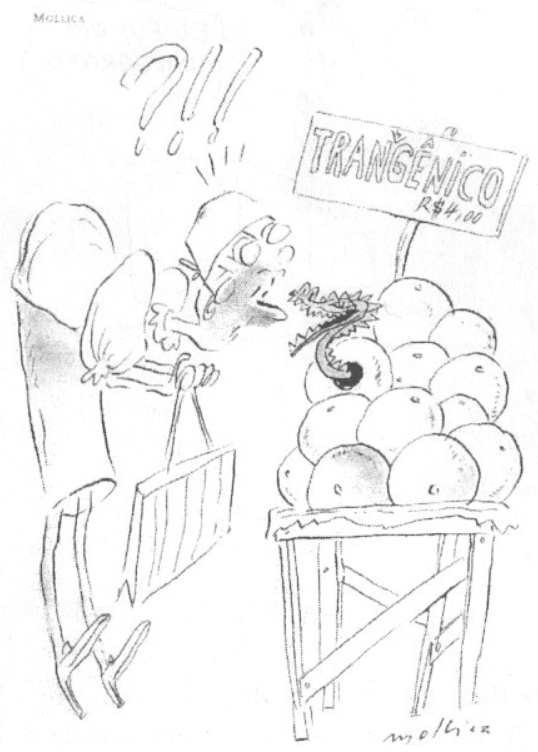

figura 4

Nos últimos anos, estudos de sexo e gênero vêm transformando nossa maneira de compreender o desenvolvimento do conhecimento em diversos campos da ciência e da arte e transformando nosso olhar sobre o mundo e, fundamentalmente, sobre mulheres e suas imagens. Laqueur, em seu estudo sobre corpo e gênero afirma que "só houve interesse em buscar evidência de dois sexos distintos, diferenças anatômicas e fisiológicas concretas entre o homem e a mulher, quando estas diferenças se tornaram 
politicamente importantes" (Laqueur, 2001:21). Surpreende pensar que "só em 1759 é que alguém se importou em reproduzir um esqueleto feminino detalhado num livro de anatomia para ilustrar suas diferenças do esqueleto masculino. Segundo o autor, "até esta época havia uma estrutura básica do corpo humano, e esta estrutura era masculina" (Laqueur, 2001:22).

Outro pesquisador, Peter Burke, comenta, em 1992, que “alguns anos [antes] seria surpreendente, se não chocante, discutir a divisão entre homens e mulheres como exemplo de divisão entre papéis sociais" (2002:75). Ele salienta os ganhos que esta nova perspectiva de análise oferece à ciência, especificamente à história, questionando, por exemplo, "os esquemas aceitos de periodização". Ele afirma que "muitos desses esquemas foram criados sem pensar nas mulheres". Complementando, o autor explica que "as mulheres ficaram virtualmente 'invisíveis' para os historiadores no sentido de que seu trabalho diário, sua influência política (em todos os níveis da política), em geral, foi subestimada, e a mobilidade social foi, via de regra, discutida apenas em termos masculinos" (2002:76).

Sob a perspectiva da "história total", Burke sugere que "seria mais útil concentrar-se nas mudanças das relações entre homens e mulheres, nas fronteiras dos gêneros e nas concepções do que é propriamente masculino e feminino" para não corrermos o risco de "perpetuar uma oposição binária entre (...) homem e mulher" ou as "exigências sociais de heterosexualidade" (2002: 77). Considerando o que é próprio de cada gênero em relação ao humor, outros pesquisadores nos mostram que até na Idade Média, o humor das mulheres é pouco registrado mas lembram, porém, que estas "fontes são predominantemente masculinas".

Estudos de feministas também "têm mostrado o quanto o humor masculino era misógino nestes períodos e a freqüência com que historiadores do sexo masculino evitaram admitir este fato" (Bremmer e Roodenburg, 2000:19). Muitas perguntas sobre o trabalho da mulher cientista ainda devem se tornar objeto de estudo. Quem é ela? Que tipos de pesquisa ela desenvolve? Que responsabilidades ela assume nas sociedades científicas e grupos de pesquisa? Seriam as mulheres, como destaca o desenho, quem oferece maior resistência aos avanços da ciência? Outra pergunta, proposta por Julia Kristeva, expande e desconstroi a discussão: “o que 
poderá significar 'identidade' ou até mesmo 'identidade sexual' num novo espaço teórico e científico, onde a própria noção de identidade é ameaçada?" (apud Laqueur, 2001:23-24).

Na charge da mulher-robô a questão da identidade soa profunda. Há discriminação sobre a mulher seja quando ela é apresentada como dominada, seja como dominadora. Criada pelo homem, a mulher robô pode ser por ele controlada. Porém, ela segura um chicote que tanto pode servir para realizar algumas fantasias sexuais (de ambos?) como para dominá-lo, via agressão física e não poder mental. A mulher real também é dada uma arma que pode ser usada para 'dominar' fisicamente o homem, mas esta é um instrumento da cozinha, lugar de onde talvez ela tenha saido para enfrentar o 'marido' cientista. Nos dois casos a mulher é submissa e passível de ser intelectualmente controlada pelos desejos do homem.

Há, por outro lado, uma possibilidade de resistência desta submissão através de um olhar que vê fraquejar a identidade masculina mostrando como ela se desorienta, desvia e é aniquilada pela possibilidade de possuir o corpo de uma mulher - mesmo que artificial. Explicitas ou implicitas, questões do corpo e do sexo, assim como de suas representações, são construídas nas relações sociais; são "produtos de momentos específicos, históricos e culturais". Isso é o que nos diz Millôr Fernandes, afirmando que "é preciso ser muito primário para achar que sexo é um ato físico".

Nesta discussão sobre objetivos, o humor brinca com noções contrastantes da ciência e do cientista e surpreende pelas contradições que levanta. Os limites da racionalidade, a fusão mente e corpo, as motivações internas e externas para o fazer científico, as relações entre ciência e vida cotidiana, a discriminação e a divisão sexual de papéis e funções na ciência são alguns dos temas sobre os quais o desenho humorístico polemiza. Jogos de significar e de criticar são iniciados. O humor sugere idéias e práticas com sua força alusiva e permissiva. 


\section{Escolher, decidir, inovar, conservar...: questôes de método}

O método científico também é alvo de sentidos e significados que, gerando contradições, negam e referendam crenças metodológicas, ora apresentando-as como um conjunto de procedimentos pré-estabelecidos, seqüenciados e descontextualizados, ora como um processo de decisões e buscas sujeito a transformações e imprevistos construidos pelo contexto. A primeira charge (figura 5) salienta, através da cor, dois sujeitos, ambos brancos e do sexo masculino: o cientista, médico odontólogo, e o paciente. $\mathrm{O}$ ambiente acinzentado é sobrecarregado de máquinas, computadores, robôs, telas, gráficos, tubos, painéis, teclados e de toda uma parafernália tecnológica que supostamente registra, controla. previne e prevê os acontecimentos relacionados ao paciente. A cor concentra vida nos sujeitos que expressam, de um lado,

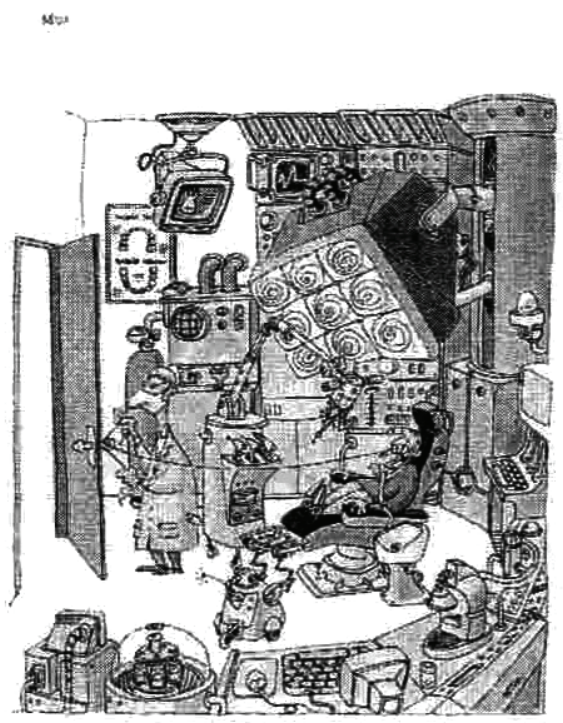


tranqüilidade, precisão e segurança e, de outro, pavor fragilidade, submissão à condição de paciente, não-ciı

O medo se estampa na cara e no corpo do pacieı pés e mãos retesados. Lembra a ineficácia da máquina tecnologia diante da dor, do sofrimento, qualquer que até uma dor conhecida, como neste caso, a da extraçãı dente. No canto superior esquerdo da parede do cons onde as máquinas deixam sobrar um pequeno espaço, ‘ tradição científica se instala através do desenho das dentárias superior e inferior. Imagem conhecida de ar consultórios, ela contrasta e se impõe frente à tecnolo computador pendurado ao teto, próximo ao quadro das arcadas, vê-se um dente com a raiz exposta que forma tridente: diabólico e atroz, unindo mito e tecnologia, s abrandar a expectativa da dor.

O médico-cientista amarra no trinco da porta ur que arrancará o dente. Expressa calma e segurança, c procedimento adotado. A imagem combina segurança e tradição e inovação, tecnologia e artesania, hábito e renovação. Não seria o método uma mistura de todos e: elementos? Como lidar com a contingência da dor fren exigências de um método? E em que medida um métodc alterar ou respeitar a experiência dos sentidos?

A relação entre cientista, método e sujeitos não t abstrata. A realidade do corpo e a prioridade da sensé fazem prevalecer a experiência sobre a escolha e conc de uma prática. Se, por um lado, a imagem do consultó como um laboratório assegura o valor da ciência enqui trabalho preciso, calculado e inovador, asséptico às vulnerabilidades da vida vivida, por outro, o método escolhido pelo cientista contrapõe-se a esta idéia e ac 'real' imediato através de uma prática do cotidiano de comuns.

O 'método da linha' é coerente com o propósito d arrancar o dente. Cientistas buscam coerência entre $n$ e propósito. A charge desestabiliza ao colocar o métod choque com o contexto. O choque é simbólico e cultura

4 Revista

Pesquisa, $\mathrm{n}^{\circ} \cdot 67$, Seção 'Cartas', p.4. métodos têm história e a relação entre método e ambie surpreende e gera polêmica. O Presidente do Conselho Diretor da Sociedade Brasileira de Pesquisa Odontológ critica o desenho dizendo: "esclareço que inúmeras sãc maneiras de fazer humor e esta, definitivamente, não f melhor" ". Para ele, o desenho contraria "uma das maio 
motivações da pesquisa científica e tecnológica da Odontologia [que] é atingir o anseio da sociedade produzindo benefícios na qualidade de vida" (Que significados teria 'qualidade de vida' para o especialista em robótica?)

Dois leitores $^{5}$ - um homem e uma mulher que não

5 Revista registram sua profissão - defendem o desenho, com veemência. O leitor diz que "gostaria de deplorar o comentário" do dentista e faz uma longa carta onde atribui à Revista e às charges a função de "desmistificar o trabalho do pesquisador ao traduzi-lo - com maestria - para o dia-a-dia dos comuns". Este leitor elogia a charge como sendo "de uma inteligência e brilhos poucas vezes vistos”, parabeniza o artista e pergunta: “Quantas palavras seriam necessárias para exprimir o espanto ao constatarmos a violência de uma extração dentária, apesar dos supostos avanços nesta área?" Além de valer muito mais que mil palavras, a imagem exprime espanto, faz constatações e viaja na história.

A leitora é concisa, se declara surpresa e não se dirige ao Presidente mas à "assessoria desse senhor" dizendo que a carta "não foi feliz ao criticar, duramente, uma das formas mais inteligentes e criativas de se fazer humor". Na opinião da leitora, "os dentistas deveriam ficar lisonjeados com a brincadeira. Que, com certeza, não foi de mau gosto”. Um método é assunto polêmico visto que sua escolha não é resultado apenas da coerência e racionalidade e estas condições não garantem sua eficiência.

Faz parte da estrutura do humor quebrar uma determinada lógica e surpreender. Nesse desenho, a surpresa nos lembra que "os motivos que levam a adotar ou a rejeitar uma determinada técnica são complexos e não obedecem a uma lógica que determinaria 'a priori' em que elas são ou não eficazes" (Fourez, 1995:78). Fourez chama atenção para este aspecto do método ao afirmar que "a única coisa que parece clara é que não existem razões 'cientificas', no sentido usual da palavra, que podem determinar de maneira clara se há ou não motivo para se firmar em uma direção qualquer" (1995: 78).

O uso da linha como método de extração de dente tem semelhanças com uma outra charge (Figura 6) que mostra um cientista esforçando-se para pegar no sono a partir da prática de contar carneirinhos saltando a cerca. As duas charges recorrem a práticas convencionais, senso comum, para sugerir a solução de problemas do nosso dia-a-dia. 
Ambas viram as costas para métodos e procedimentos 'cientificos' utilizando-se do conhecimento comum. Como na maioria dos outros desenhos, o cientista é homem, maduro, calvo e branco. Mas Doly, do sexo feminino, substitui os antigos carneirinhos. Tradição e inovação, crença e hábito voltam a se combinar nesta charge. Pode-se discutir a idéia. expressa por Fourez, de que "nossos modelos partem sempre de uma visão ligada à vida cotidiana, de uma visão espontânea, evidentemente condicionada pela cultura" (1995:66).

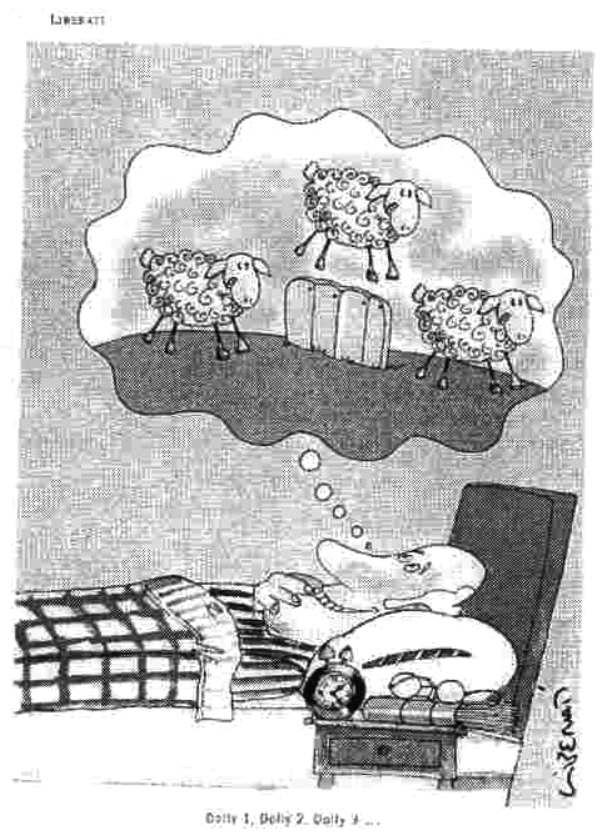

figura 6

Objetos como livros, óculos e relógio compõem o cenário para a visão do cientista como um sujeito sempre racional que tem a vida medida e controlada pela razão. Porém, ao contar ovelhinhas, o cientista desgarra-se da ciência e parece agarrar-se ao que define Fourez: "o procedimento cientifico se parece mais com outras decisões da existência do que com 
a imagem etérea, puramente ligada ao mundo das idèias, que se tem normalmente" (1995: 79).

A última charge, ainda lidando com o método científico (figura 7) joga com o acaso, com a imprevisibilidade, com a relação às vezes descontinua entre método e resultados. A mulher - camponesa colhedora de frutos - olha com escárnio para Da Vinci, completamente desconjuntado, e questiona sobre suas intenções visivelmente não realizadas. Cientistaartista, símbolo da experimentação e da observação, evocação da contraposição metodológica entre razão e sentidos ainda hoje presente. Da Vinci faz prevalecer sua experiência e destaca outra invenção: o cortador de grama. Um longo e sinuoso caminho de grama podada evidencia a eficácia prática do invento, investindo-lhe de status cientifico. Mas a estrutura retorcida que se vê ao chão denuncia a intenção ocultada nas palavras do cientista.

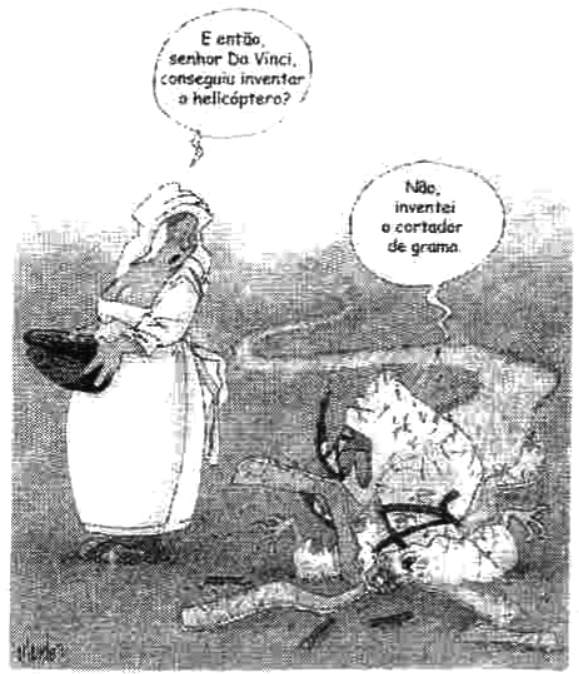


A importância do sujeito na construção do conhecimento é ressaltada neste desenho. Como "não há procedimentos regulares para alcançar êxito" (Azanha, 1992:79) na ciência, ação e imaginação percorrem o processo científico. A observação de regras e a aplicação de critérios não são exigências para uma ação inteligente ou criativa. Pelo contrário, como Azanha expõe, "o êxito na investigação científica, naquilo que ela tem de mais relevante que é a criação de novas idéias (hipóteses, teorias, conceitos), é refratário a qualquer regulação garantidora de resultados" (1992:17). O cortador de grama não substituiu o helicóptero mas Da Vinci continua despertando interesse de pesquisadores sobre suas notas, pelas suas incansáveis experimentações e inventos. Porém, sujeitos altamente criativos e/ou inteligentes podem não ter critérios, nem caráter. Como diz Rubem Alves, "os cientistas, ao fazer ciência, não são movidos por razões quantitativas, científicas. São movidos por curiosidade, prazer, inveja, competição, narcisismo, ambição profissional, dinheiro, fama, autoritarismo" (1999:127).

\section{Resultados e implicações da prática científica}

Duas charges finalizam esta discussão. A primeira (figura 8) questiona a relação entre cientista e os resultados da ciência. Pergunta inevitável: quem comanda quem? O desenho é simples e cheio de indagações. Sabemos que a ciência satisfaz mas também cria necessidades. Criação e transformação de necessidades podem se dar tanto na direção do refinamento como da brutalização. As contradições de cada momento histórico configuram estas realidades.

Neste desenho, o robô, criação da ciência, parece, à primeira vista, comandar o cientista, homem, branco criador. Mas o cientista não se entrega: seu sonambulismo protege-o dizendo que é comandado apenas porque não está, ele mesmo, sob controle. Poderia o robô ter feito o cientista dormir? Se o robô é quem aparentemente dirige o cientista e tem, no nariz, uma luz que o ilumina, cabe a um aparelho emissor/receptor levar à cabo a tarefa. $\mathrm{O}$ poder percorre a cena seja pela ausência - no caso do sonâmbulo; pelo controle - no caso do aparelho emissor/receptor; ou pela posse, caso do robô que detém o aparelho controlador. A charge questiona os limites e resultados da parceria, hoje inevitável, entre ciência e 


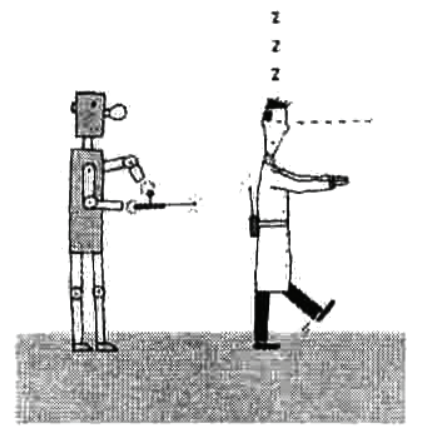

figura 8

tecnologia. Questiona o valor e a funçăo da ciência na construção de um sujeito que possa governar seu próprio destino.

A última charge (figura 9) expõe um fragmento de realidade transformada pela ciência e dá visibilidade à relação entre cientista, ciência e sociedade. Assassinato e suicidio perdem sua distinção, confundem-se. Instala-se uma situação de impasse moral, social. O humor provoca o pensamento para transitar do virtual para o real, criando novos problemas e novas indagaçoes. Se a construção de determinadas 'ordens' perceptiva e explicativa é objetivo da ciência, a criaçāo e percepçāo da desordem, sua enunciação e busca de reorganização também são parte da prática cientifica e suas implicaçóes.

\section{Implicaçôes da ciência, 'aplicaçôes' do humor}

Os desenhos selecionados podem ser lidos como uma crítica à noção de ciência como atividade neutra, objetiva. verdadeira, racional, sempre "a serviço do progresso e do bem estar de toda a humanidade" (Andery, 2001: 436). Ao exagerar certas pretensões da ciência, o humor faz aparecer suas polêmicas e interpela seus direcionamentos. Estes desenhos também podem ser lidos como uma reverência à 
ciência, seu status, verdades e mentiras que a ciência apregoa sobre seus objetivos, métodos, resultados e implicações. Lembrando aquele velho ditado que diz: "falem mal mas falem de mim", além de crítica ou denúncia, o humor também funciona para criar aliados, reunir pessoas em torno de certas idéias e marcar territórios na consciência. O humor tambèm funciona para humanizar as práticas cientificas e reforçar seu valor e importância na sociedade. Publicados na seção final de PESQUISA (última página), o humor instala um caráter de libertadade na relaçẫo com os leitores e desfaz o clima geralmente tenso e compenetrado que se tem em relação à ciência.

figura 9

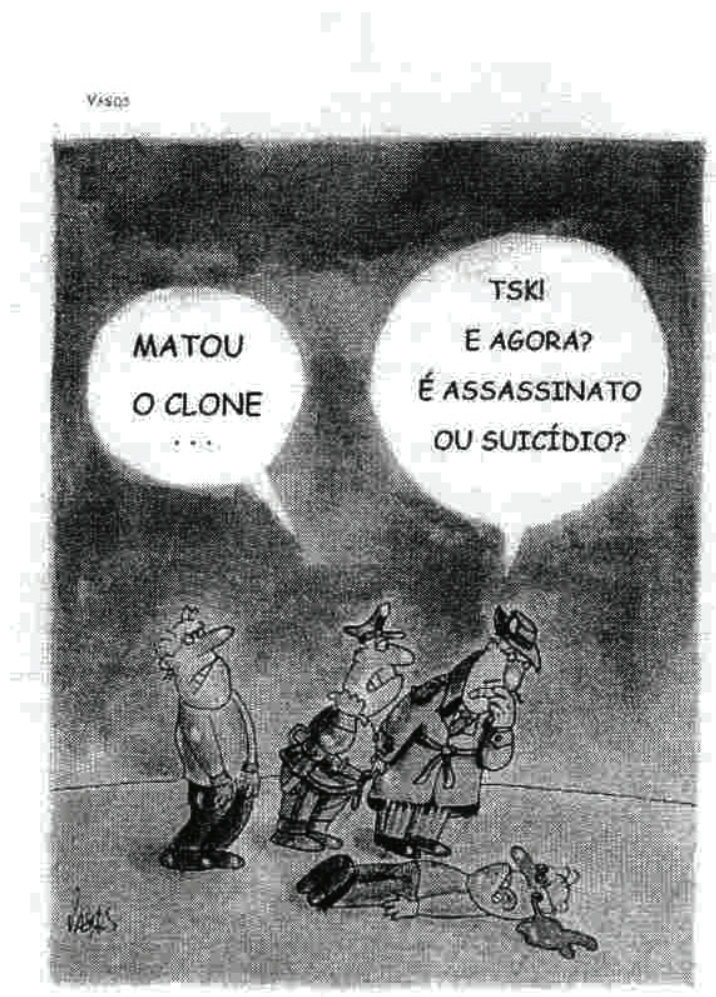

O leitor que defende a charge sobre o método da linha para arrancar o dente escreve que, através dos desenhos, "o hermético torna-se cristalino e o jargão cientifico já não consegue mais afastar o interesse dos demais. Sentimo-nos próximos daqueles que parecem falar a mesma linguagem. Passamos a compreender seus objetivos, admirar seu 
trabalho, sentir simpatia como a que sentimos por nossos próximos amigos. E, como amigos, podemos também brincar, por que não?"

Esta função social do humor é tema do antropólogo Henk Driessen que discute o "humor como delimitador das fronteiras do grupo, formados por símbolos e atitudes que ajudam a desenvolver um tipo de esprit de corps". Segundo ele, para os antropólogos, as histórias de humor "expõem as emoções e vulnerabilidades dos pesquisadores de campo" e "não só marcam a identidade profissional da antropologia como parecem estimular a sensação de superioridade diante das disciplinas correlatas" (2000:271). O interesse, a proximidade, a admiração e a simpatia, conforme aponta o leitor, são disposições e sentimentos sobre e para a ciência que o humor cria e pode fazer crescer em relação a outras formas de representar o mundo.

O humor também desempenha um "papel crucial na criação de uma esfera pública" do conhecimento, conforme comenta Townsend. Esta pesquisadora nos conta como o humor ajudou a "a construir um espaço público, um campo ou arena onde poderiam ser discutidos todos os tipos de idéias, fossem elas políticas, sociais e morais". Além de "estabelecer um sentido de comunidade" esta pesquisadora reconhece que "as ambigüidades do humor lhe permitiram servir a muitas funções, transpondo as fronteiras da cultura baixa e alta, atraindo públicos diferentes, e sendo interpretado de muitas maneiras" (Townsend 2000:228-229)

Finalizando, cabe perguntar, como o faz Gombrich: este tipo de humor convenceria a alguém que ainda não estivesse convertido para esta visão? Ou: não seria exatamente a função da sátira pictórica, conforme questiona este autor, "pregar para os convertidos?" (2000: 194-195). É no recinto autorizado de uma revista científica que o humor prega, para cientistas, a humanidade e as contradições da ciência. "Se a pregação aos convertidos fosse sem função", conforme argumenta Gombrich, "não haveria sermão, entra dia, sai dia, em todas as igrejas e templos do mundo". Os sermões "renovam e reforçam" a união entre os membros de uma comunidade.

Gombrich explica que ao reforçar certos estereótipos o humor contribui para a criação do sepso de identidade do grupo. Essa identidade sustenta-se e é sustentada pela pressuposição de superioridade de um grupo sobre os outros os não pertencentes. Velhos temas e estereótipos estão 
presentes nestas charges. O repertório confirma a análise de Gombrich de que a principal caracteristica desse gênero é seu conservadorismo. Mesmo conservador, o humor têm a capacidade de popularizar idéias, valores e processos com as quais brinca. Ele lança luz sobre temas e contradições da ciência e fazendo isso, informa, forma e educa. Marca visualmente territórios onde ciência e arte se aproximam e instituem realidades comunicantes.

\section{Referências}

ALVES, R. Entre a Ciência e a sapiência: o dilema da educação. São Paulo: Loyola, 1999.

ANDERY, M. et al. Para compreender a ciência. São Paulo: EDUC, 2001. AZANHA, J. M. P. Uma idéia de pesquisa educacional. São Paulo: EDUSP/FAPESP, 1992.

BREMMER, J. e ROODENBURG, H. Introdução: humor e história. In: Uma história cultural do humor: Rio de Janeiro: Record, 2000.

BURKE, P. História e Teoria Social. São Paulo: UNESP, 2002.

DRIESSEN, H. Humor, riso e campo: reflexões da antropologia. In: Uma história cultural do humor. Rio de Janeiro: Record, 2000.

FOUREZ, G. A construção das ciências: introdução à filosofia e à ética das ciências. São Paulo: UNESP, 1995.

GOMBRICH, E. H. The Uses of Images: studies in the social function of art and visual communication. London: Phaidon Press, 2000.

LAQUEUR, T. Inventando o sexo: corpo e gênero dos gregos a Freud. Rio de Janeiro: Relume Dumará, 2001.

TOWNSEND, M. L. O humor e a esfera pública na Alemanha do século XIX. In: Uma história cultural do humor. Rio de Janeiro: Record, 2000.

Irene Tourinho é Professora Titular da UFG e Coordenadora do Mestrado em Cultura Visual da FAV-UFG. É consultora ad hoc do CNPq, membro do Grupo de Pesquisa Educação e Visualidade, membro do Conselho Consultivo da Galeria da Fav e do Museu de Arte Contemporânea de Goiânia. Membro do Comitê Editorial da Revista Comunicação e Educação da Escola de Comunicação e Artes da USP. 